Article

\title{
Assessing the Level of Inter-Sectoral Policy Integration for Governance in the Water-Energy Nexus: A Comparative Study of Los Angeles and Beijing
}

\author{
Gregory N. Sixt ${ }^{1,2}$, Claudia Strambo ${ }^{3, *}$, Jingjing Zhang ${ }^{4}$, Nicholas Chow ${ }^{5}$, Jie Liu ${ }^{6}$ \\ and Guoyi Han ${ }^{3}$ \\ 1 Abdul Latif Jameel Water and Food Systems Lab (J-WAFS), Massachusetts Institute of Technology (MIT), \\ 77 Massachusetts Avenue, Cambridge, MA 02139, USA; sixt@mit.edu \\ 2 Stockholm Environment Institute (SEI) (at the time of research), 11 Curtis Avenue, \\ Somerville, MA 02144-1224, USA \\ 3 Stockholm Environment Institute (SEI), P.O. Box 24218, SE-104 51 Stockholm, Sweden; guoyi.han@sei.org \\ 4 Lawrence Berkeley National Laboratory, 1 Cyclotron Road, Berkeley, CA 94720, USA; jingjingzhang@lbl.gov \\ 5 Center for Innovation, University of California Los Angeles Luskin Center for Innovation, 3323 Public \\ Affairs Building, Box 951656, Los Angeles, CA 90095, USA; nchow@luskin.ucla.edu \\ 6 Institute of Water Sciences, College of Engineering, Peking University, Beijing 100871, China; \\ jie.liu@pku.edu.cn \\ * Correspondence: claudia.strambo@sei.org
}

Received: 29 July 2020; Accepted: 28 August 2020; Published: 3 September 2020

check for updates

\begin{abstract}
As concerns around water scarcity and energy security increase, so too has interest in the connections between these resources, through a concept called the water-energy nexus. Efforts to improve the integration of water and energy management and to understand their cross-sector relevance are growing. In particular, this paper develops a better empirical understanding on the extent to which governance settings hinder and/or enable policy coherence between the water and energy sectors through a comparative analysis of two case studies, namely, Los Angeles County, California, the United States, and the city of Beijing, China. This paper examines the extent to which the institutional context enables policy coordination within (vertically) and between (horizontally) the water and energy sectors in Beijing and Los Angeles. To do so, we propose a framework for analyzing policy integration for the water energy nexus based on environmental policy integration (EPI). The results highlight the multiple and flexible approaches of EPI in nexus governance, not least with regards to horizontal and vertical policy integration, but also in terms of explicit (i.e., intended) and implicit (i.e., unintended) coordination. The level of nexus-focused policy integration is highly dependent on the motivation at the local context and the criteria to evaluate policy success in each sector.
\end{abstract}

Keywords: water-energy nexus; environmental policy integration; comparative governance; urban sustainability; Beijing; Los Angeles

\section{Introduction}

Water availability and use is deeply interconnected with energy production [1]. Throughout the last century, these connections were largely ignored-it was assumed that energy for providing and using water would remain cheap and abundant, and energy systems were developed under the assumption that water would remain easily accessible [2]. As concerns around water and energy security grow, so too has interest in the interlinkages between these resources, known as the water-energy nexus 
(WEN) [3]. Efforts to improve the integration of water and energy management and to understand their cross-sector relevance are growing.

Infrastructure and technology are at the core of the WEN, and the nexus is often characterized in resource use efficiency terms and operational interdependencies [4]. There are few studies that explore the policy and institutional dimensions of the WEN [4-8] or that compare the WEN across countries $[9,10]$. The governance landscape and the processes that dictate how resources are allocated critically influence how technical information on trade-offs between sectoral objectives is translated into action [11]. Yet, it is not yet clear how governance contexts of different countries impact the barriers and pathways to water and energy policy coherence.

The United States and China play an important role in WEN. Collectively, they account for 33\% of global energy production, for $38 \%$ of total global energy consumption [12], and for $27 \%$ of global water withdrawals [13]. Both the United States and China have committed to ambitious targets to reduce fossil fuel consumption and associated greenhouse gas emissions, as well as to policies to improve the sustainable use of water and energy resources. This study was funded by the United States Department of Energy and the Ministry of Science and Technology of China to explore WEN governance in megacities in both countries (Beijing and Los Angeles), where water scarcity poses challenges to long-term economic sustainability. For this study, we limit the scope to the water-energy nexus, and exclude the increasingly popular and broader water-energy-food nexus [8], because of the prioritization of water and energy supplies in policy priorities for both urban areas (see Section 3).

The overall goal of this paper is to develop, through two comparative case studies, a better empirical understanding on the extent to which different governance settings hinder and/or enable policy coherence between the water and energy sectors. Specifically, this paper seeks to answer the following two questions: (1) What are the main similarities and differences in the governance of the water and energy nexus in Beijing and Los Angeles? (2) To what extent does the institutional context enable policy coordination within (vertically) and between (horizontally) the water and energy sectors in Beijing and Los Angeles?

The paper is structured as follows. Section 2 presents the conceptual framing of the paper and the methods. Section 3 presents the analysis for the case studies and compares the findings between the two cases. The discussion and conclusion are found in Section 4, which also includes a discussion on the relevance of our findings and the contributions of this paper to the broader literature base.

\section{Materials and Methods}

\subsection{Conceptual Framework: Environmental Policy Integration and the Water-Energy Nexus}

The WEN concept aims to identify the synergies and trade-offs in how these sectors are managed and, ultimately, aims to lead to the synergetic management of these two sectors to improve efficiency in resource use. Nexus governance thus seeks to achieve greater environmental sustainability by improving policy coherence between these two sectors [14], with policy coherence being defined as 'an attribute of policy that systematically reduces conflicts and promotes synergies between and within different policy areas to achieve the outcomes associated with jointly agreed policy objectives' [15] (p. 108).

To date, nexus-based governance interventions have been largely limited to either technical, administrative analysis for optimal resource allocation or to providing information to decision makers about nexus dynamics to inform policy decisions [14]. A dearth of real-world examples remain of where nexus concepts have been operationalized to achieve inter-sectoral policy integration. Additionally, the literature base that could connect the nexus approach to decision-making and policy-making processes is superficial and lacks the nuance, evidence-based research, and theoretical elements for supporting governance $[14,16]$.

The nexus approach can be seen as part of the umbrella concept of integrative environmental governance (IEG) [17]. Building off of Visseren-Hamakers [17], Weitz et al. [14] noted that IEG provides a useful pool of knowledge through which to analyze nexus-based integrative governance. 
IEG encompasses a collection of concepts focused on the relationships between environmental governance instruments and governance systems in the context of complex, fragmented governance systems [8,17]. Of the IEG concepts described by Visseren-Hamakers [17], environmental policy integration (EPI) is especially relevant to the comparative water-energy policy integration research focus of this paper. It seeks to increase the rationality and effectiveness of resource governance by bringing together different policy actors to identify mutual gains or more cost-effective policy opportunities [18], bringing insights into various dimensions of policy coherence across the whole policy process.

EPI is based on the normative viewpoint that the environment needs better protection and that all societal sectors should work toward achieving this end [18]. Generally speaking, EPI is understood to involve the integration of environmental objectives into traditionally non-environmental sectoral policy decisions [19]. This can involve sectors that are deeply tied to the environment, but that may be managed largely independent of the broader environmental context.

This framing applies to both the water and energy sectors. Water supply and sanitation and energy policies are traditionally oriented toward meeting demands through engineering-infrastructure approaches, where the environment plays a tertiary role. However, both sectors are dependent on and impact the environment and each other. This means that achieving WEN governance is fundamentally about achieving EPI within and across these sectors.

EPI as a guiding governance principle includes cross-governmental approaches, where policy integration is sought both horizontally between sectors and vertically within sectors [19-22]. Horizontal integration is about incorporating "new" objectives into existing sectoral policies at a given political level, while vertical integration is about putting in place procedures and mechanisms to improve implementation effectiveness across political levels within a sector [20,23,24]. Thus, EPI not only involves the integration of environmental priorities into sectoral governance, it can also be used for the integration of environmental priorities between sectors $[20,25]$, in this case the water and energy sectors.

To date, EPI has primarily been a Eurocentric policy principle, with notable applications in Sweden, the Netherlands, and the United Kingdom [26-28]. It has received little attention as a governance strategy in the United States and China. In fact, a literature review yielded no studies on EPI in the United States and only one in China [29]. Additionally, comparative studies assessing the levels of EPI achieved in different countries and sectors are limited [19,22]. Of the cross-national comparative studies that do exist, most focus on European countries [22] or at the broad national level in countries of the Organization of Economic Cooperation and Development [30]. At the same time, there have been only a few empirical studies on WEN governance [31,32].

This study fills the following three gaps in the literature: (1) it applies EPI analysis to new, non-European geographies; (2) it adds to the limited literature base, comparing EPI between two different countries; and (3) it provides empirical insights into the governance of the WEN at a subnational level.

\subsection{Methods and Analytical Framework}

There is no consensus in the literature on what analytical factors should be used in EPI analyses [25]. Jordan and Lenschow [22] suggest the following two basic perspectives through which to frame EPI studies: political systems approaches and policy analysis approaches. They note that the first approach focuses on insights into how political systems and institutions influence EPI, which can be derived from comparative country studies, and the second, on the scope and effectiveness of different implementation measures by focusing on particular points at which attempts at EPI are made.

For this analysis, we use a comparative case study research design as informed by political system approaches. This allows us to highlight the role of institutions in enabling or hindering policy integration in the WEN at a subnational level (a brief description of the two case studies, Los Angeles County and the city of Beijing can be found in Supplementary Materials). While both cases share commonalities 
(e.g., large urban areas in dry regions heavily reliant on imported water, high potential climate change impacts to water resources, complex regional water and energy infrastructure, and serious water and energy resource conflicts), the institutional design and politics that govern policy-making in the United States and China are very different (e.g., federalist democratic vs. state-oriented political systems, bottom-up vs. top down, respectively).

Inspired by Hussey and Schram [25,33], we see EPI has three roles to play in the process of water-energy governance, namely steering, enabling, and facilitating. Our analysis explores the extent to which governance settings steer, enable, and facilitate policy coordination within (vertically) and between (horizontally) the water and energy sectors in Los Angeles and Beijing.

More specifically, EPI works to steer or guide a particular policy goal through institutional settings; provides the methodological tools, technical approach, financial/human resource, and budgetary structure to enable policy integration; and facilitates the policy integration process via networking to mediate a participatory and transparent coordination among relevant stakeholders. In the process of steering, enabling, and facilitating, one could distinguish the activities between explicit and implicit ones. For example, renewable energy policy helps to steer the institutional legitimacy of energy use in the water sector, however, it was not initiated with the goal of water-energy policy integration. In that case, we see it placed as an implicit factor for EPI.

Furthermore, given the presence of the steering, enabling, and facilitating roles we identified for the EPI process, the second part of the framework allows us to evaluate to what extent the EPI process is shaped by the external factors and the primary policy outcomes that are of concern to the water-energy decision makers. As far as the motivations for EPI are concerned, we recognize that external pressures, such as local water/energy resource deficiency or other socio-economic and political agendas, could be the key determinants in initiating EPI in the first place. Internally, for integration to be effective, the key decision makers should ideally have aligned criteria to define what successful EPI policies or mechanisms look like.

Bearing these considerations in mind, we developed the analytical framework laid out in Table 1. In this framework, external factors refer to the external pressures imposed from resource, social, economic, and political systems that motivate decision makers to take or not take actions to initiate EPI. Steering EPI refers to the presence of organizational and/or legal arrangements that provide directions for coordination mechanisms between the energy and water sectors. EPI steering can be either explicit (i.e., water and energy coordination is specifically mentioned in a policy setting) or implicit (i.e., sectoral policy that has cross-sectoral benefits). 
Table 1. Analytical framework to evaluate environmental policy integration (EPI) motivations, processes, and outcomes.

\begin{tabular}{lll}
\hline \multicolumn{1}{c}{ Key EPI Roles and Elements } & \multicolumn{1}{c}{ Key Questions under Each EPI to be Asked } \\
\hline External factors (motivation)
\end{tabular}

\section{Enabling the EPI process}

- To what extent has there been a budget specifically allocated or budgetary structure enabled to achieve the EPI objectives?

Financial and budgetary structure, technical capacity, and human resource
- Are there shared evaluation procedures, approaches, and tools among water and energy sectors?

- Is there enough/relevant human resource capacity present for achieving EPI objectives?

\section{Facilitating the EPI process}

- $\quad$ Are there formal regulations, networks, or stakeholder involvement mechanisms for communication?

Communication structure, stakeholder involvement, networking, and learning
- Do informal relations play a role in policy coherence?

- To what extent is there training and carryover of institutional knowledge?

\section{EPI outcome}

- What are the formal/mandate criteria to evaluate policy

\section{Results}

\subsection{Los Angeles Case Study}

Water governance in the United States follows a federalist model, where the federal government provides a basis of legal framing, but allows regional and local actors to wield greater influence over the resources in order to enable flexibility and encourage efficiency. The federal government is involved in surface water management in limited situations, such as in the management of federally funded dams and water diversion projects, or with transboundary river treaties (e.g., the Colorado River Compact). Groundwater governance is administered at the state level in the United States, with federal involvement limited to situations where groundwater use overlaps with federal laws (e.g., the Endangered Species Act) [34,35].

In California, the principal sources of water include: the California State Water Project (SWP), transferring water from Northern California to Southern California; the Central Valley Project, providing essential agricultural water for food production in California's Central Valley; and the Colorado River Aqueduct, which allocates additional water from the Colorado River to be moved to Southern California. 
These water management decisions are upheld by different agencies, often in mutual coordination, with the SWP being managed by the California Department of Water Resources (DWR), while the latter two are managed by the federal Bureau of Reclamation.

Governance of the electricity system in the Western United States is largely characterized as having decentralized decision making and fractious coordination among the different electricity markets [36]. In Southern California, The Los Angeles Department of Water and Power is the largest municipal utility in the United States, serving more than four million residents. To a large extent, the utility is subject to climate and energy regulations occurring at the state level. As parts of the water infrastructure are located outside the county's jurisdictional boundary, Los Angeles is also heavily dependent on energy generated outside the county to power its imported water system [37].

About $12 \%$ of California's total energy use is related to water [38]. A burgeoning example in California's WEN that demonstrates the need for a greater inter-sectoral EPI comes from water managers. For instance, the Metropolitan Water District of Southern California has developed climate action plans to guide future actions in reducing greenhouse gasses (GHGs) from the water infrastructure. Here, WEN is increasingly dominating discussions, as the state transitions to using energy-intensive water resources when the drought intensifies, and these include recycled water solutions, desalinated water, imported water, and groundwater resources. Recognizing the potential for the water-energy sectoral misalignment that could lead to environmentally undesirable outcomes, there has been an increased awareness of the need for a greater horizontal EPI-the motivation for this analysis. Across California, and in the Los Angeles region specifically, many researchers have begun quantifying the energy, water, and environmental tradeoffs of alternative water supply strategies like recycling [38-42]. However, few have explicitly examined the policy factors that help to explain EPI outcomes, as we do in the following sections.

\subsubsection{External Factors (Motivation)}

California is well known for its leading efforts to curb climate change. Most WEN policy integration in Los Angeles is closely linked to state-level climate initiatives. The California Global Warming Solutions Act of 2006, AB32, ref. [43] established the legislative authority and common policy objectives (emissions reduction targets) and strategic processes (e.g., the Climate Action Team) for cross-sector coordination [44]. The act provided a common language (i.e., GHG emission targets) for the energy and water sectors in their respective policy-making processes and implementation.

In addition to meeting climate change targets, activities related to addressing energy use for water can also be driven by economic concerns. The economic rationality is typically embedded in the cost of long-distance water delivery, groundwater pumping, and wastewater and water treatments such as desalination. The cost of a traditional supply of water varies from source to source. As a customer of the SWP, in 2018, the Metropolitan Water District (MWD)'s power and water costs were USD 447 million, nearly $30 \%$ of the total yearly expenses [45]. MWD's water supply rates in 2016 (i.e., Tier 1) were about double the rates of a decade ago, i.e., an approximately $20 \%$ increase in real costs $[46,47]$. Because of water resource constraints, future new sources of water supply come at even higher costs [48].

Given the rapidly increasing cost of maintaining secure water supplies, energy use has been increasingly accorded only secondary importance to water utilities' primary mandate of ensuring the availability of safe water for human consumption [49]. Despite energy's notable impacts on operations and costs, many water systems see little incentive to conserve energy because of their ability to directly pass any just and reasonable cost of providing water service through to customers. For utilities, the result of this is the provision of a more secure water product, at no additional real cost—arguably a greatly diminished economic incentive for energy conservation.

\subsubsection{Steering the EPI Process}

Evidence of explicit EPI process steering is found in a number of state policies, including SB1425, which requires the California Environmental Protection Agency (CalEPA) to oversee the development 
of a registry for GHG emissions. Under Rulemaking R.13-12-011, the California Public Utilities Commission (CPUC) is required to develop a partnership framework between investor-owned energy utilities and the water sector to co-fund programs that reduce energy consumption by the water sector. Perhaps the most evident and long-standing WEN policies are the water and energy efficiency standards for buildings (i.e., Title 24) developed by the California Energy Commission (CEC).

Within each sector, there are also implicit initiatives that have cross-sectoral benefits as components. This is particularly true in the energy sector, where the goals of increasing renewable energy and strengthening end-use standards have co-benefits to reduce GHG emissions and energy use for the water sector, as indicated in the previous section. In the water sector, the goals of increasing local sourcing also have the co-benefit of reducing the energy used for importing water, as indicated in the governor's California Water Action Plan: 2016 Update [50].

The organizational arrangements to coordinate these explicit and implicit efforts are supported by an inter-agency coordination setting in California. To achieve the climate goals mandated by AB32, the Climate Action Team (CAT) was established to coordinate statewide efforts to implement carbon emission reduction programs and the state's Climate Adaptation Strategy [51]. A sub-group within CAT, the Water-Energy Team (WET-CAT), is the only state-level inter-sectoral entity with the mandate to manage the WEN or to have the stated goals of doing so. WET-CAT is officially tasked with integrating regulations at a regional scale, by planning, research, data analysis, and coordinating funding for regional projects to '(1) achieve large water and energy savings and efficiencies, (2) reduce greenhouse gas emissions, and (3) reduce or eliminate risks from changing hydrological and ocean conditions' [52] (p. 1).

Finally, among local utilities, institutionalized intersectoral collaboration occurs, especially on the end-use side, but it is largely informal. The one example of formalized institutional coordination is the Master Inter-Utility Agreement (MIUA) between the Los Angeles Department of Water and Power's (LADWP) and the Southern California Gas Company's (SoCalGas) Joint Efficiency Programs. The MIUA launched 12 joint programs between 2012-2017 [53,54] that greatly enhanced water-energy efficiency program planning and implementation at a local level.

\subsubsection{Enabling the EPI Process}

Historically speaking, the energy sector has been conspicuously well-funded when compared with the water sector, and as water gains importance through scarcity, water managers are seeking creative strategies to find funding, including examining inter-sectoral funding for water-energy savings. The timing is opportune for intersectoral funding connecting the water and energy sectors. It reflects a combination of factors, including climate change effects on sources of water, reducing emissions from energy production, and the linkages between an increased focus on local sources of water and the immense energy footprint required to provide water to Los Angeles.

Reflective of the interconnectivity of these issues, there are some explicit examples of budgetary allocation to support achieving EPI objectives. On regulating California's Cap-and-Trade revenue, statutes enacted in 2012 through AB 1532 [55] direct the use of auction revenue to GHG reduction activities, for example, for energy efficiency, renewable energy, or GHG reductions associated with water use and supply. The DWR, the California Department of Food and Agriculture, and the CEC have all developed water and energy grant programs, and beginning in 2015, the DWR began a water-energy grant program, leveraging approximately USD 19 million in grants to save the water and associated energy use, some of which have gone to the LA county [56]. Budgetary allocation is also sourced from utilities. In April 2013, LADWP and SoCalGas announced a USD 440 million investment plan for joint energy efficiency programs [57].

It is insufficient to enable EPI by solely investing; appropriate incentives are key to resource allocation. CPUC has laid the groundwork for providing a mechanism for investment in energy efficiency by decoupling return-on-investment for private energy utilities from relying solely on the volume of energy sold [44]. This process also allows for private energy utilities to gain 
energy efficiency credits through cross-sector investment in water efficiency programs, which are implemented by public water utilities [44].

Following the legislature requirements and cross-sectoral programs mentioned earlier, there are a couple of notable tools that have been developed specifically and explicitly for the water and energy nexus. For example, the GHG reporting tools used in the Water-Energy Nexus GHG Registry provide a common methodological framework to account for the locational and technical variations of the energy intensity of the water supply and use across the state [58]. Another tool, The Water Energy Cost Effective Calculator, was developed by the CPUC to help utilities and the commission evaluate the embedded energy for water, and how cost effectiveness should be analyzed for nexus programs [59].

\subsubsection{Facilitating the EPI Process}

To engage in the WEN programs mentioned in the earlier sections, there are several stakeholder involvement channels available, including periodic WET-CAT meetings, which provide a venue for both water and energy actors, as well as state and local agencies to communicate key issues regarding plans and procedures for water utilities to meet and track the required climate targets/progress. Likewise, under the CPUC's WEN program, periodic stakeholder meetings are held, and documentations made publicly available.

Information transparency is a standard procedure in the public policymaking setting in California. What is unique to WEN coordination/communication is the presence of an inter-agency organization that institutionalized EPI communication both vertically (between state and local) and horizontally (between the water and energy sectors).

\subsubsection{EPI Outcome}

For the water sector, ensuring long term water resource security and sustainable use to maintain ecological functions are the two major focuses in California. These in turn are translated as criteria such as, long-term water supply contracts, water efficiency, agriculture output per water input, water quality standard, habitant restoration, salinity, stream flow, groundwater sustainability, etc. Beyond sectoral concerns, reduced GHG emissions from the state's water supply is a mandate target for DWR.

For the energy sector, achieving climate targets is a high priority for the industry. Under the framework of $\mathrm{AB} 32$, the CEC and CPUC enforce renewable energy portfolio standards that indirectly reduce GHG emissions for the water sector. The CEC also oversees both water and energy efficiency at the end use side, which are exemplified in the Title 24 building codes and various appliance standards.

It is evident that climate targets and efficiency are common policy evaluation criteria for both sectors, despite their differences in the policy contexts and motivation.

\subsection{Beijing Case Study}

China's governance structure is a multi-layered hierarchy, which stems from the National People's Congress downward. The various organs within this structure are divided by function, territory, and rank, making any policy initiative the responsibility of many separate organizations [60]. Although China's government is unitary, substantial power has been delegated to subnational authorities at the provincial, city, and district levels. In most aspects of energy and water policy, the major responsibility of the sub-national governments is to adapt national policies, laws, and regulations to local conditions, and then to enforce them to meet their disaggregated targets [61]. Therefore, in the Beijing context, WEN governance is very much determined by central decisions and local implementation challenges.

In Beijing, development policy is overseen by the Beijing Municipal Commission of Development and Reform (BMCDR), which is also responsible for energy infrastructure planning, local coal mining, and electricity utilities management, as well as energy conservation and efficiency programs. Still, energy governance is fragmented across public agencies, with the Beijing Municipal Commission of 
Housing and Urban-Rural Development (BMCoHURD), the Beijing Municipal Commission on Rural Affairs (BMCoRA), and the Beijing Municipal Commission of Economy and Information Technology (BMCoEIT) being responsible for energy conservation in buildings, rural energy development, and energy savings in industry, respectively. In addition, the Beijing Municipal Administration of Quality and Technology Supervision (BMAQTS) is responsible for supervising and inspecting the implementation of energy efficiency standards.

To avoid such a level of fragmentation in the water sector, the Beijing Water Authority was established in 2004, as the main agency responsible for water use and supply integrated management in the city. Nevertheless, other sectors remain involved in governing water, such as the BMAQTS regarding water use standards, the Beijing Office of the South-to-North Water Diversion Project Construction Committee, and the Beijing Municipal Planning and Land Resources Commission, which monitors groundwater pollution and develops infrastructure plans for both the water and energy sectors.

As a result, at the Beijing level (like at the national level, see [62]), there are agencies that are involved in both water and energy policy design and implementation in Beijing, such as the BMCDR, the BMCoHURD, the BMAQTS, and the Beijing Municipal Bureau for Environmental Protection, which is responsible for reducing air and land pollution, as well as improving water quality.

Despite the interest in resource conservation, the WEN concept, as such, has not yet gained much traction in the policy arena. Studies of the WEN in China are still in the initial stages $[63,64]$. Although cities are the foci of energy consumption, very few WEN studies have examined urban areas in China [65]. For instance, Hu et al. [66] assess the WEN in Beijing, focusing on the water used in electricity production and supply, as well as the electricity used for water supply, treatment, utilization, and post-use. Liu et al. [67] explore the spatial dimension of the WEN of Beijing, and find that more water for energy is consumed outside Beijing's boundaries than within its boundaries. They also highlight that meeting water policy objectives implies an increase in energy use, making it harder for Beijing to meet its carbon emission control targets.

\subsubsection{External Factors}

Since the beginning of the 2000s, Chinese leadership has pursued a more balanced approach to development in response to growing social, political, and environmental challenges associated with the previous decades of rapid economic growth, emphasizing harmony between humans and nature and promoting efficient use of resources [68-70]. Within this context, water scarcity is of particular concern, with former premier Wen Jiabao once saying that water shortages threatened 'the very survival of the Chinese nation' [71]. Lately, there has been a greater recognition of the need to manage energy and water resources in a synergetic way, although the emphasis has been mostly on water for energy [72].

In Beijing as well, water resources represent a major constraint for development in the long term [73]. Ensuring sufficient water supply has been a priority for policy-makers for over a decade [74]. Meanwhile, energy scarcity is of much less concern. Since 2013, efforts to curb air pollution led to the closing of all the Beijing's coal power plants and to an increased share of electricity being sourced from other provinces. While this electricity remains mostly coal-based and is sourced from water-stressed areas [75], its implications for water scarcity and air quality are beyond Beijing policy-makers' jurisdiction.

\subsubsection{Steering the EPI Process}

Resource efficiency and conservation have constituted a core element of China's five-year plans—the national economic and social development plans-since 2006. National policy documents include WEN relevant binding policy targets and objectives, although the nexus is not referred to explicitly. Within the energy sector, these include a cap on total energy consumption at 5 billion tons of coal equivalent for 2020 , combined with a cap of $58 \%$ on coal's share in energy consumption, a ban 
on coal mining activities in drinking water source protection areas, improving water efficiency and reducing water pollution throughout energy production and coal industrial processing, and plans for further hydropower development in the (water rich) southwestern regions [76-78].

Within the water sector, nexus-relevant targets and objectives were established in the Five-Year Plan for Ecological and Environmental Protection [79] further strengthened through the "three red lines" policy (see Supplementary Materials), and include capping the total water supply and use, increasing efficiency in water consumption, and ensuring better water quality across all sectors of the economy [80]. "Energy" is explicitly mentioned in the National Water Resources Comprehensive Plan [81], but only from the perspective of "water for energy" for key regions that need water supply guarantees, including Beijing. It encourages, for instance, the use of recycled water, groundwater, and seawater for energy production (for thermal cooling).

Overall, at a national level, there is thus more emphasis on water resources constraints to energy development than the other way around [62]. Furthermore, the energy and water sectors make their policies and set the targets separately in China, primarily based on the current situation and projected needs of each sector [72]. For example, although there were many ministries involved in designing the "three red lines policy", the national energy agency was not part of the process, nor were local energy agencies involved in the definition of Beijing's specific three red lines policy targets.

China has several policy instruments that are relevant for the WEN. One is a new volume-based water resource tax piloting scheme that after a two-years pilot trial in Hebei Province, was extended in 2018 to nine additional provinces, including Beijing. These provinces host many coal mines and thermal power plants, as well as high water consuming industries such as steel, cement, and chemicals [82]. With the 2016 tax reform, most other resource taxes have moved towards being price-based rather than volume-based [83], and this suggests that for water, there is a special emphasis on resources efficiency. Minimum tax rates were established for the pilot provinces, however Beijing set higher levels, the highest among all of the other provinces.

"Energy for water" is indirectly considered through the cost of electricity. However, if this is not a constraining factor for water supply, then "energy for water" rarely becomes a major concern for water governance. One typical example is the utilization of recycled water in Beijing; from 2004 to 2016, recycled water use in Beijing increased from 0.2 billion cubic meters to more than 1 billion cubic meters, corresponding to an increase from $6 \%$ to $26 \%$ of Beijing's total water supply [84]. This has important energy implications, as the energy intensity of recycled waters is at least two to four times that compared with utilizing groundwater and surface water [64].

The main command and control instrument from a WEN perspective has been the use of resource efficiency standards. Since 2012, many standards for water intake have been updated or established for specific industrial sectors, including many key energy-consuming sectors such as thermal power (GB/T 18916.1-2012), petroleum refining (GB/T 18916.3-2012), coking [85], and coal to ammonia (GB/T 18916.8-2006). In 2017, the National Institute of Standardization proposed adding water use standards for converting coal to chemical products. However, these standards are intended to assign water limits to individual projects, rather than addressing integrated resource management at a macro level [62]

Even though recycled water use is not constrained by the "three-red-line" policy, the Beijing government has taken initial measures to limit the energy intensity of recycled water through the "Regulation of Energy Consumption in Municipal Wastewater Treatment" (DB11/T 1118-2014). Implemented in March 2015, the regulation sets up, for the first time, electricity consumption standards for wastewater treatment plants at different scales and is expected to lead to about an $8 \%$ increase in energy savings [86].

There is no institution at the national level nor at Beijing's level that coordinates the governance of the energy and water sectors. Like the NRDC at a national level, the Beijing Municipal Commission of Development and Reform does have both the water and energy sectors under its overarching mandate; however, environment, water, and energy policy implementation are still tackled separately. To date, 
attention to the WEN has mainly been from academia, but there are still limited good quality data on the WEN-especially at a local level [87].

The $\mathrm{Xi}$ administration has made significant efforts to improve environmental governance and reduce vertical policy fragmentation [88-90]. However, this has not yet led to WEN explicit governance institutional arrangements. One possible reason is that environmental policy is still very much focused on addressing air, water, and soil pollution, rather than resources efficiency and productivity, which remains more of a sectorial objective. In addition, there are still considerable margins within both the water and energy sectors in order to improve resources efficiency [91-93], and to reduce institutional fragmentation [64,94-96], before starting to increase cross-sectorial resources efficiency.

\subsubsection{Enabling the EPI Process}

Even if they rely strongly on higher level authorities for project financing [97], local governments are also contributing financially to policy implementation $[98,99]$. According to government policy, part of the revenues from taxes need to be used for resource efficiency activities, and these can be significant-indeed, $90 \%$ of the revenue stemming from the water resources tax is allocated to local governments [100].

However, the environmental public spending structure appears to not be very conducive to WEN integrated governance. Indeed, local cadres tend to mobilize and support only those administrative units with the highest chance of succeeding in obtaining project funding, so that they meet their policy mandates and receive positive performance evaluations. As a result, resources end up being concentrated on projects and places that have the highest potential to gain the interest and approval of higher-level cadres [97]. This may represent an obstacle for WEN initiatives at a local level, as the WEN is not an explicit policy concern yet.

China has some technical tools that enable cross-sectoral resources efficiency analysis, such as its environmental impact assessment system, which requires major construction projects, including energy infrastructure and energy-intensive industries, to be strictly evaluated regarding their water impact [101]. Still, the emphasis is mostly on sectoral or project-specific resource efficiency, with very little explicit attention to WEN interactions. While academics have been using the concept of virtual water [102,103], there is so far no policy indicator or target expressed in the energy or water embeddedness at a national or local level.

In addition, it is unclear whether the staff in the relevant agencies are best suited to promote and implement WEN governance. Indeed, studies in water governance have shown that because of their technocratic nature, when more integrative governance schemes have been put in place, such as water basin commissions, these have failed to function as integrated platforms [104,105].

\subsubsection{Facilitating the EPI Process}

Regarding stakeholder consultation, the Chinese EIA system includes stakeholder participation [92], and the public official monitoring process was modified in 2009 to include non-party members [29]. However, even with the introduction of new requirements for environmental information disclosure in 2008, to enhance the transparency and political legitimacy of governmental work, public participation in policy is far from being the norm [96].

Information about informal relations and learning opportunities are unfortunately very limited. Overall, the way authority and rank influence policy-making in China tends to go against cross-sectoral governance [29]. Indeed, in China, authority is fragmented not only by function and territory, but also by rank-every public office has a bureaucratic rank assigned to it, and units of the same rank cannot issue binding orders to each other [106].

However, while central directives are being more strongly enforced [89], at the same time, there has been more autonomy given to subnational authorities regarding how to reach the different targets. Innovative governance mechanisms have emerged, with increased collaboration across government agencies and civil society to address challenges and new entrepreneur activities by both governmental 
and other actors to reach environmental objectives [96]. This suggests that the policy space at a subnational level is open to new ideas and WEN measures could become of interest.

\subsubsection{EPI Outcome}

Resource efficiency is a common target for both the water and energy sectors, but it is pursued within, not across, sectors. While there have been calls for more synergetic management of water and energy resources, in general, important gaps remain between ambitions set at the national level and policy outcomes at the local level [96], and none of the targets being evaluated for cadre performance are about cross-sectoral efficiency.

\subsection{Comparing Findings between Los Angeles and Beijing}

In this section, we summarize the findings for each of the cases and compare them. In Table 2, we highlight the key findings from our analysis. We then highlight the most important commonalities and differences between the two cases.

Table 2. Comparing the environmental policy integration (EPI) criteria between Los Angeles and Beijing.

\begin{tabular}{|c|c|c|}
\hline $\begin{array}{c}\text { WEN Governance Evaluation } \\
\text { Criteria }\end{array}$ & Los Angeles WEN Governance & Beijing WEN Governance \\
\hline \multicolumn{3}{|c|}{ External pressures (motivation) } \\
\hline $\begin{array}{l}\text { Resource, social, economic, } \\
\text { and political context }\end{array}$ & $\begin{array}{l}\text { Because of resource scarcity, water } \\
\text { security and sustainability are the top } \\
\text { concerns for water regulators and utilities. } \\
\text { Energy for water is largely driven by } \\
\text { mandated climate targets and, to some } \\
\text { degree by the concern for economic } \\
\text { viability-it is expensive to move water } \\
\text { around in California. }\end{array}$ & $\begin{array}{l}\text { A few WEN issues are explicitly } \\
\text { mentioned at a national level, driven by } \\
\text { concerns of pollution and water resource } \\
\text { scarcity. In Beijing, water scarcity issues } \\
\text { are much higher on the policy agenda } \\
\text { than energy. The WEN policy is set mainly } \\
\text { at a national level, while implementation } \\
\text { is delegated to lower government levels. }\end{array}$ \\
\hline \multicolumn{3}{|c|}{ Steering the EPI process } \\
\hline $\begin{array}{l}\text { Initiating institutions and } \\
\text { organizational arrangement }\end{array}$ & $\begin{array}{l}\text { Both explicit and implicit steering } \\
\text { mechanisms are present in California, } \\
\text { again, largely driven by the climate } \\
\text { legislation AB32 (implicit). Many other } \\
\text { water-energy-relevant legislative and } \\
\text { quasi-legislative actions have been } \\
\text { introduced following AB32. } \\
\text { Organizational arrangements, such as } \\
\text { the inter-agency Water-Energy Team } \\
\text { (WET-CAT), were created to coordinate } \\
\text { efforts to primarily address } \\
\text { the climate/energy impacts of the state's } \\
\text { water system. There are some elements of } \\
\text { state-local coordination (for example, } \\
\text { between the California Public Utilities } \\
\text { Commission or the California Energy } \\
\text { Commission and utilities), } \\
\text { but the coordination efforts remain at } \\
\text { a state level. }\end{array}$ & $\begin{array}{l}\text { The initiating institutions are primarily at } \\
\text { a national level, although Beijing has } \\
\text { taken initiative in integrative governance } \\
\text { arrangement by creating the BWA and, } \\
\text { with regard to WEN policy mechanisms, } \\
\text { by introducing consumption standards } \\
\text { for wastewater treatment plants. Still, } \\
\text { WEN governance measures remain } \\
\text { mostly implicit, and there are no WEN } \\
\text { specific indicators to monitor their } \\
\text { effectiveness. In terms of organizational } \\
\text { arrangements, there is no agency to } \\
\text { explicitly coordinate water-energy } \\
\text { policy-making and implementation. }\end{array}$ \\
\hline \multicolumn{3}{|c|}{ Enabling the EPI process } \\
\hline $\begin{array}{l}\text { Financial and budgetary } \\
\text { structure, and technical } \\
\text { capacity }\end{array}$ & $\begin{array}{l}\text { Intersectoral funding is provided by both } \\
\text { public agencies (for example via revenues } \\
\text { from cap and trade) and also from utilities. } \\
\text { It is unclear whether this funding is } \\
\text { sufficient to mitigate the climate impacts } \\
\text { of the water sector as required. Besides } \\
\text { financial resources, technical frameworks } \\
\text { have been developed for GHG accounting } \\
\text { and cost-benefit analysis under several } \\
\text { legislatively established WEN programs. }\end{array}$ & $\begin{array}{l}\text { Beijing has considerable financial } \\
\text { resources available for investing in WEN } \\
\text { measures. However, there are no explicit } \\
\text { financial mechanisms for WEN } \\
\text { governance. In addition, cadre incentive } \\
\text { structures and the technocratic nature of } \\
\text { implementing agencies do not work } \\
\text { in favor of cross-sectoral governance. }\end{array}$ \\
\hline
\end{tabular}


Table 2. Cont.

\begin{tabular}{|c|c|c|}
\hline $\begin{array}{c}\text { WEN Governance Evaluation } \\
\text { Criteria }\end{array}$ & Los Angeles WEN Governance & Beijing WEN Governance \\
\hline \multicolumn{3}{|c|}{ Facilitating the EPI process } \\
\hline $\begin{array}{l}\text { Communication structure, } \\
\text { stakeholder involvement, } \\
\text { and earning }\end{array}$ & $\begin{array}{l}\text { The presence of an inter-agency } \\
\text { organization (WET-CAT) has provided } \\
\text { an institutionalized channel to facilitate } \\
\text { both vertical (between state and local) and } \\
\text { horizontal (between water and energy } \\
\text { sectors) commutation on EPI issues. }\end{array}$ & $\begin{array}{l}\text { While there have been improvements } \\
\text { in terms of the disclosure of } \\
\text { environmental information, public access } \\
\text { to information remains restricted. Overall, } \\
\text { the way authority and rank influence } \\
\text { policy-making work counters to } \\
\text { cross-sectoral governance. }\end{array}$ \\
\hline \multicolumn{3}{|c|}{ EPI outcome } \\
\hline $\begin{array}{l}\text { Criteria to evaluate policy } \\
\text { success }\end{array}$ & $\begin{array}{l}\text { Despite the differences in sectoral } \\
\text { priorities, having the common evaluation } \\
\text { criteria in place (i.e., climate targets and } \\
\text { efficiency) is critical for the water and } \\
\text { energy sectors in order to evaluate their } \\
\text { own policy success. }\end{array}$ & $\begin{array}{l}\text { Despite increasing incentives in the cadre } \\
\text { annual evaluation system for public } \\
\text { officials to balance environmental health } \\
\text { and resources efficiency with economic } \\
\text { growth, important gaps remain between } \\
\text { ambitions set at the national level and } \\
\text { policy outcomes at the local level, } \\
\text { and none of the targets being evaluated } \\
\text { for cadre performance are about } \\
\text { cross-sectoral efficiency. }\end{array}$ \\
\hline
\end{tabular}

Despite very different political systems, there are a number of commonalities between LA and Beijing with regards to WEN governance. In both cases, concerns about water scarcity are greater than for energy supply, and, therefore, policies that improve water efficiency for energy services delivery are more common than the reverse. In both cases, the motivations behind WEN-relevant measures and institutional mechanisms go beyond resource efficiency. They respond to climate change mitigation in LA and improving air and environment quality in general in Beijing.

The institutions and policy mechanisms related to WEN governance are, however, significantly different between the two case studies. In LA, there is a formal institution specially dedicated to address WEN issues, WET-CAT, which was set up to support climate mitigation. In Beijing, despite the existence of a few agencies and departments with a mandate that spans both sectors, in practice, policy targets and implementation mechanisms are set up separately for each sector. Another important difference is the existence of common technical frameworks and indicators for water and energy policy in the LA case, but not in Beijing. Importantly, in both cases, some measures and mechanisms that contribute to WEN policy coherence are implicit, i.e., they are not intentionally addressing this issue; rather, they are set up through sectoral policy, but have cross-sectoral benefits. Overall, LA appears to have more explicit WEN governance mechanisms (such as the WET-CAT, the MIUA, the Water-Energy Cost Effective Calculator, or joint efficiency programs) than Beijing (mostly energy requirements for water treatment).

\section{Discussion and Conclusions}

This study illustrates to what extent the institutional context can hinder or enable policy coherence between the water and energy sectors at a local level. Our analysis both supports previous analysis about institutional settings and policy coherence [15,107], and reveals some unexpected ways in which the institutional context intersects with WEN governance. Firstly, the existence of a common goal beyond cross-sector efficiency, such as mitigating climate change in LA, is an important driver of WEN governance. This confirms the results of [31], who also noted the importance of the broader goal of decarbonization in the emergence of water-energy nexus governance in Amsterdam. The LA case also highlight the significance of common evaluation criteria, which further illustrates how the existence of performance-based indicators are important factors for encouraging policy coordination [108].

Secondly, we find that a strong resource efficiency policy goal at national and subnational levels is not necessarily conductive to explicit water-energy nexus governance, as shown by the Beijing 
case. Despite a strong policy narrative of resource efficiency and the increasing importance given to related indicators in policy evaluation - which, in China's political system, trickle down the governance levels-resource efficiency measures continue to be planned and implemented within each sector separately. This may be explained by the fact that there is still considerable room for improvement within each sector in terms of both resource efficiency and intra-sectorial integration. In addition, as a significant share of electricity in Beijing is imported from other provinces, the energy use for water is beyond the reach of city authority. Another explanatory factor is the significant asymmetry between concerns about water and energy scarcity, which is also observed in LA.

Thirdly, our study points to the great importance of common policy evaluation criteria between the water and energy sectors in order to improve policy coherence, even if these indicators are not necessarily framed in WEN terms, as is the case in LA with GHG mitigation targets. In Beijing, horizontal integration between the water and energy sectors is hindered by the traditional role of authority and rank in policy-making, which prevails in the country. Despite the existence of a potential funding mechanism, at a local level, financial resources for policy implementation are tightly limited to the expressed priorities of higher levels of government. This works against water-energy policy integration, as the WEN is not an explicit priority policy concern, and policy evaluation criteria do not include WEN indicators.

The main contributions of this paper are to illustrate empirically how WEN policy integration takes place at a subnational level, and to show that it does not have to happen intentionally. In fact, co-benefits can exist without explicit planning and facilitation, especially if the criteria to evaluate policy success are aligned between water and energy sectors through external factors. Examples of implicit WEN governance include the goal of increasing local water sourcing in LA, as well as the water resource tax and resource efficiency standards in Beijing.

The next steps would be to evaluate the effectiveness of implicit WEN governance vs. explicit WEN governance for cross-sectoral policy coherence, whether and where it is more effective to have explicit (or implicit) WEN governance across the different governance functions. The literature on EPI and groups of regimes for instance argues that coherence strategies that are influential at a decision-making level are not automatically influential in implementation, and vice versa, and, therefore, that coherently stated policy objectives do not necessarily translate to coherent implementation and outcomes [8]. Adding a new coordinating institution, for instance, is not necessarily the most effective strategy [27]. This appears to support the findings of White and colleagues [32], who remark that stakeholders discussing appropriate policy measures to improve WEN governance did not suggest that any new significant federal or state major policies were necessary, and that easing existing rules and regulations might have a better outcome.

In addition to the system benefits brought about by the unintended policy integration, in Amsterdam as well, institutional flexibility has proven to be a key factor for improving WEN governance [31]. In our case studies, institutional flexibility means that institutional activities conducted by WEN stakeholders at different levels are an important mechanism for successful WEN governance. A strong state institutional support in California seems to play a variety of roles, including steering, facilitating, and performance evaluation. In this case, the local actors also enjoyed a great degree of freedom for WEN implementation, and enacted policy innovations to meet the local needs, while in the Beijing case, we observed much less WEN steering and facilitating effects despite the existence of a strong state.

The importance of institutional flexibility, therefore, suggests that future work should move beyond the discussion about "state vs. local" or "regulation vs. market". Institutional works can stem from different sources, as WEN issues are inherently complex. Such challenges often require institutional works from boundary spanning actors that are able to think and work in different thematic areas. The boundary spanners, for example, could be a state coordinating agency, local networks, non-governmental organizations (NGOs), and entrepreneurs, among others. We expect that the types of institutional activities and contributions of boundary spanning actors will vary from case to case. 
This is because they are highly dependent on the nature of local WEN issues and on the embedded institutional environments of the actors situated in a given jurisdiction.

Supplementary Materials: The following are available online at http://www.mdpi.com/2071-1050/12/17/7220/s1, Description of study area.

Author Contributions: Cconceptualization, G.H., G.N.S., C.S., and J.Z.; methodology, G.N.S., C.S., and J.Z.; software, N.A.; validation N.A.; formal analysis, N.C., G.N.S., C.S., and J.Z.; investigation, N.C., J.L., G.N.S., C.S., and J.Z.; resources, N.A.; data curation, N.A.; writing (original draft preparation), G.H., Jie Liu, N.C., G.N.S., C.S. and J.Z; writing (review and editing), N.C., J.L., G.N.S., C.S., J.Z.; visualization, N.A.; supervision, G.H. and G.N.S.; project administration, G.N.S.; funding acquisition, N.A. Authorship must be limited to those who have contributed substantially to the work reported. All authors have read and agreed to the published version of the manuscript.

Funding: This study was financially supported by the CERC-WET project, funded by the National Key Research and Development Program (No. 2018YFE0196000) of the Ministry of Science and Technology of China and the US Department of Energy. It also received financial support from the Swedish International Development Cooperation Agency (Sida) and UC Berkeley.

Acknowledgments: The authors would like to thank Chunmiao Zheng, Yan Zheng, Hong Yang, and Eric Kemp-Benedict for their valuable comments and suggestions during the manuscript preparation. The authors are also grateful to Annette Huber-Lee for her role in acquiring funding for this study.

Conflicts of Interest: The authors declare no conflict of interest.

\section{References}

1. Healy, R.W.; Alley, W.M.; Engle, M.A.; McMahon, P.B.; Bales, J.D. The Water-Energy Nexus: An Earth Science Perspective; U.S. Geological Survey: Reston, VA, USA, 2015.

2. Pacific Institute. Water-Energy Nexus. Available online: https://pacinst.org/issues/water-energy-nexus/ (accessed on 26 March 2019).

3. Dai, J.; Wu, S.; Han, G.; Weinberg, J.; Xie, X.; Wu, X.; Song, X.; Jia, B.; Xue, W.; Yanga, Q. Water-energy nexus: A review of methods and tools for macro-assessment. Appl. Energy 2018, 210, 393-408. [CrossRef]

4. Scott, C.A.; Pierce, S.A.; Pasqualetti, M.J.; Jones, A.L.; Montz, B.E.; Hoover, J.H. Policy and institutional dimensions of the water-energy nexus. Energy Policy 2011, 39, 6622-6630. [CrossRef]

5. Appelbaum, B. Water \& Sustainability (Volumes 1-4): US Electricity Consumption for Water Supply \& Treatment-The Next Half Century; Topical Report 1006787; Electric Power Research Institute: Concord, CA, USA, 2002.

6. Sovacool, B.K.; Sovacool, K.E. Identifying future electricity-water tradeoffs in the United States. Energy Policy 2009, 37, 2763-2773. [CrossRef]

7. Stein, C.; Barron, J.; Moss, T. Governance of the Nexus: From Buzz Words to a Strategic Action Perspective; Nexus Network Think Piece Series, Paper 003; Economic \& Social Research Council: Swindon, UK, 2014.

8. Weitz, N.; Strambo, C.; Kemp-Benedict, E.; Nilsson, M. Closing the governance gaps in the water-energy-food nexus: Insights from integrative governance. Glob. Environ. Chang. 2017, 45, 165-173. [CrossRef]

9. Siddiqi, A.; Anadon, L.D. The water-energy nexus in Middle East and North Africa. Energy Policy 2011, 39, 4529-4540. [CrossRef]

10. Venkatesh, G.; Chan, A.; Brattebø, H. Understanding the water-energy-carbon nexus in urban water utilities: Comparison of four city case studies and the relevant influencing factors. Energy 2014, 75, 153-166. [CrossRef]

11. Cairney, P. The Science of Policymaking. In The Politics of Evidence-Based Policy Making; Palgrave Macmillan: London, UK, 2016; pp. 1-12.

12. International Energy Agency. Key World Energy Statistics; International Energy Agency: Paris, France, 2016.

13. AQUASTAT. FAO's Information System on Water and Agriculture. Food and Agriculture Organization of the United Nations. Available online: http://www.fao.org/nr/water/aquastat/countries/index.stm (accessed on 16 February 2020).

14. Weitz, N.; Strambo, C.; Kemp-Benedict, E.; Nilsson, M. Governance in the Water-Energy-Food Nexus: Gaps and Future Research Needs; Working paper; Stockholm Environment Institute: Stockholm, Sweden, 2017.

15. Nilsson, M.; Zamparutti, T.; Petersen, J.E.; Nykvist, B.; Rudberg, P.; Mcguinn, J. Understanding Policy Coherence: Analytical Framework and Examples of Sector-Environment Policy Interactions in the EU. Environ. Policy Gov. 2012, 22, 395-423. [CrossRef] 
16. Leck, H.; Conway, D.; Bradshaw, M.; Rees, J. Tracing the Water Energy Food Nexus: Description, theory and practice. Geogr. Compass 2015, 9, 445-460. [CrossRef]

17. Visseren-Hamakers, I.J. Integrative environmental governance: Enhancing governance in the era of synergies. Curr. Opin. Environ. Sustain. 2015, 14, 136-143. [CrossRef]

18. Nilsson, M.; Persson, Å. Framework for Analysing Environmental Policy Integration. J. Environ. Policy Plan. 2003, 5, 333-359. [CrossRef]

19. Runhaar, H.; Driessen, P.; Uittenbroek, C. Towards a systematic framework for the analysis of environmental policy Integration. Environ. Policy Gov. 2014, 24, 233-246. [CrossRef]

20. Lafferty, W.M.; Hovden, E. Environmental policy integration: Towards an analytical framework. Environ. Politics 2003, 12, 1-22. [CrossRef]

21. Duncan, R.; Jordan, A. Environmental policy integration in the UK. In Governance for the Environment: A Comparative Analysis of Environmental Policy Integration; Goria, A., Sgobbi, A., Eds.; Edward Elgar Publishing: Cheltenham, UK, 2010; pp. 157-178.

22. Jordan, A.; Lenschow, A. Policy paper environmental policy integration: A state of the art review. Environ. Policy Gov. 2010, 20, 147-158. [CrossRef]

23. Giessen, L. Vertical Policy Integration. In Green Issues and Debates: An A-to-Z Guide; Schiffman, H., Robbins, P., Schiffman, H.S., Eds.; SAGE Publications: Thousand Oaks, CA, USA, 2011; pp. 486-489.

24. Giessen, L. Horizontal Policy Coherence. In Green Issues and Debates: An A-to-Z Guide; Schiffman, H., Robbins, P., Schiffman, H.S., Eds.; SAGE Publications: Thousand Oaks, CA, USA, 2011; pp. 293-296.

25. Weber, M.; Driessen, P.P.J. Environmental policy integration: The role of policy windows in the integration of noise and spatial planning. Environ. Plan. C Gov. Policy 2010, 28, 1120-1134. [CrossRef]

26. Lenschow, A. Environmental Policy Integration: Greening Sectoral Policies in Europe; Earthscan: London, UK, 2002.

27. Persson, A. Different Perspectives on EPI. In Environmental Policy Integration in Practice: Shaping Institutions for Learning; Nilsson, M., Eckerberg, K., Eds.; Earthscan: London, UK, 2007; pp. 24-47.

28. Nilsson, M.; Eckerberg, K.; Persson, Å. Introduction: EPI Agendas and Policy Responses. In Environmental Policy Integration in Practice: Shaping Institutions for Learning; Nilsson, M., Eckerberg, K., Eds.; Earthscan: London, UK, 2007; pp. 1-24.

29. Bina, O. Environmental Governance in China: Weakness and Potential from an Environmental Policy Integration Perspective. China Rev. 2010, 10, 207-239.

30. Jacob, K.; Volkery, A. Institutions and Instruments for Government Self-Regulation: Environmental Policy Integration in a Cross-Country Perspective. J. Comp. Policy Anal. Res. Pract. 2004, 6, 291-309. [CrossRef]

31. Covarrubias Perez, I.; Spaargaren, M.; Boas, G. Network governance and the Urban Nexus of water, energy, and food: Lessons from Amsterdam. Energy. Sustain. Soc. 2019, 9, 14. [CrossRef]

32. White, D.; Jones, J.; Maciejewski, R.; Aggarwal, R.; Mascaro, G. Stakeholder Analysis for the Food-Energy-Water Nexus in Phoenix, Arizona: Implications for Nexus Governance. Sustainability 2017, 9, 2204. [CrossRef]

33. Hussey, K.; Schram, A. Policy integration and the energy-water nexus: Accounting for and managing the links. In Securing Sustainable Energy Futures in Europe and Australia; Winand, P., Pearman, G., Eds.; PIE-PeterLang Publishers: Brussels, Belgium, 2011; pp. 245-268.

34. Peck, J.C. Legal Challenges in Government Imposition of Water Conservation: The Kansas Example. Agron. J. 2015, 107, 1561-1566. [CrossRef]

35. Sixt, G.N.; McCarthy, A.C.; Portney, K.E.; Griffin, T.S. Water Diplomacy at the macro scale: Agricultural groundwater governance in the High Plains aquifer region of the United States. In Interdisciplinary Collaboration for Water Diplomacy: Problem-Driven Research and Practice; Islam, S., Smith, K.M., Eds.; Routledge: London, UK, 2019; 30p.

36. Lenhart, S.; Nelson-Marsh, N.; Wilson, E.J.; Solan, D. Electricity governance and the Western energy imbalance market in the United States: The necessity of interorganizational collaboration. Energy Res. Soc. Sci. 2016, 19, 94-107. [CrossRef]

37. Yates, D.; Miller, K.A. Climate Change: Impacts and Responses. Int. J. Clim. Chang. Impacts Responses 2013, 4, 49-63. [CrossRef]

38. The California Department of Water Resources. Water Energy Nexus. Available online: https://water.ca.gov/ Programs/All-Programs/Climate-Change-Program/Water-Energy-Nexus (accessed on 14 August 2020). 
39. Porse, E.; Mika, K.B.; Escriba-Bou, A.; Fournier, E.D.; Sanders, K.T.; Spang, E.; Stokes-Draut, J.; Federico, F.; Gold, M.; Pincetl, S. Energy Use for Urban Water Management by Utilities and Households in Los Angeles. Environ. Res. Commun. 2020, 2, 015003. [CrossRef]

40. Sanders, K. The energy trade-offs of adapting to a water-scarce future: Case study of Los Angeles. Int. J. Water Resour. Dev. 2016, 32, 362-378. [CrossRef]

41. Tchobanoglous, G.; Cotruvo, J.; Crook, J.; McDonald, E.; Oliveieri, A.; Salveson, A.; Trussels, R.S. Framework for Direct Potable Reuse; Water Reuse Foundation, American Water Works Association, Water Environment Federation, National Water Research Institute: Alexandria, VA, USA, 2015.

42. Fang, A.J.; Newell, J.P.; Cousins, J.J. The Energy and emissions footprint of water supply for southern California. Environ. Res. Lett. 2015, 10, 114002. [CrossRef]

43. California. Assembly Bill No. 32-California Global Warming Solutions Act of 2006; California Assembly: Sacramento, CA, USA, 2006.

44. Oliver, G.; Hussey, K. Cross-sectoral governance of the climate, energy and water sectors: A 'Rubik's cube' analysis of cross-sectoral co-ordination. In Climate, Energy and Water: Managing Trade-Offs, Seizing Opportunities; Pittock, I.J., Hussey, K., Dovers, S., Eds.; Cambridge University Press: Cambridge, UK, 2016; pp. 172-197.

45. The Metropolitan Water District of Southern California. Annual Report for the Fiscal Year; The Metropolitan Water District of Southern California: Los Angeles, CA, USA, 2018.

46. The Metropolitan Water District of Southern California. Annual Report for the Fiscal Year; The Metropolitan Water District of Southern California: Los Angeles, CA, USA, 2016.

47. The Metropolitan Water District of Southern California: Annual Report for the Fiscal Year; The Metropolitan Water District of Southern California: Los Angeles, CA, USA, 2006.

48. Pierce, G.; Chow, N.; Gmoser-Daskalakis, K.; Roquemore, P.; Heil, N. Analyzing Southern California Supply Investments from a Human Right to Water Perspective. The Proposed Poseidon Ocean Water Desalination Plant in Orange County; UCLA Luskin Center for Innovation: Los Angeles, CA, USA, 2019.

49. United States, Safe Drinking Water Act. 1974. Available online: https://www.epa.gov/sdwa (accessed on 3 November 2018).

50. California Natural Resources Agency. California Water Action Plan: 2016 Update; California Natural Resources Agency: Sacramento, CA, USA, 2016.

51. Climate Action Team \& Climate Action Initiative. California Climate Change. Available online: https: //www.climatechange.ca.gov/climate_action_team (accessed on 2 November 2018).

52. Water Energy Team-Climate Action Team (WET-CAT). Climate Change and the Water-Energy Nexus: Statewide Opportunities to Reduce Greenhouse Gases and Adapt to a Changing Climate. Water-Energy Team-Climate Action Team Update 2011; California Waterboards: Sacramento, CA, USA, 2011.

53. Rendler, D. LA Business Council: Energy Efficiency Workshop. In Proceedings of the LA Business Council Downtown Energy Efficiency Workshop, Los Angeles, CA, USA, 15 June 2015.

54. Mugi, L. Come Together: Turning Utility Collaboration Into a Strategic Energy and Water Efficiency Resource. In Proceedings of the 2017 ACEEE National Conference on Energy Efficiency as a Resource, Litchfield Park, AZ, USA, 1 November 2017.

55. California Assembly Bill 1532 - California Global Warming Solutions Act of 2006 (Ammended 2012); California Assembly: Sacramento, CA, USA, 2012.

56. California Natural Resources Agency. California Water Action Plan Implementation Report: 2016 Summary of Accomplishments; California Natural Resources Agency: Sacramento, CA, USA, 2017.

57. Los Angeles Department of Water and Power. Master Inter-Utility Agreement Between Southern California Gas Company and Los Angeles Department of Water and Power for Energy Efficiency, Resource Savings, and Related Actions; Los Angeles Department of Water and Power: Los Angeles, CA, USA, 2012.

58. The Climate Registry. Water-Energy Nexus Registry. Available online: https://www.theclimateregistry.org/ programs-services/california-water-energy-nexus-registry (accessed on 13 November 2018).

59. California Public Utilities Commission. Water/Energy Nexus. Available online: http://www.cpuc.ca.gov/ General.aspx?id=4139 (accessed on 13 November 2018).

60. Hou, E. Briefing Paper on Water Governance Structure in Beijing, PRC; University of British Colombia: Vancouver, BC, Canada, 2000.

61. Andrews-Speed, P. Energy Policy and Regulation in the People's Republic of China; Kluwer Law International: London, UK, 2004. 
62. Zhang, J.; Zhou, N.; Khanna, N.; Fridley, D.; Yi, S.; Jiang, S.; Liu, X. Water-Energy Nexus in China. A study on the National Scale; Lawrence Berkeley National Laboratory: Berkeley, CA, USA, 2018.

63. Qin, Y.; Curmi, E.; Kopec, G.M.; Allwood, J.M.; Richards, K.S. China's energy-water nexus-Assessment of the energy sector's compliance with the "3 Red Lines" industrial water policy. Energy Policy 2015, 82, 131-143. [CrossRef]

64. Li, X.; Liu, J.; Zheng, C.; Han, G.; Hoff, H. Energy for water utilization in China and policy implications for integrated planning. Int. J. Water Resour. Dev. 2016, 32, 477-494. [CrossRef]

65. Fang, D.; Chen, B. Linkage analysis for the water energy nexus of city. Appl. Energy 2017, 189, 770-779. [CrossRef]

66. Hu, G.; Ou, X.; Zhang, Q.; Karplus, V. Analysis on energy-water nexus by Sankey diagram: The case of Beijing. Desalin. Water Treat. 2013, 51, 4183. [CrossRef]

67. Liu, J.; Li, X.; Yang, H.; Han, G.; Liu, J.; Zheng, C.; Zheng, Y. The Water-Energy Nexus of Megacities Extends Beyond Geographic Boundaries: A Case of Beijing. Environ. Eng. Sci. 2019, 36, 778-788. [CrossRef]

68. Economy, E. The River Runs Black: The Environmental Challenge to China's Future; Cornell University Press: Ithaca, NY, USA, 2004.

69. Guo, S.; Guo, B. China in Search of a Harmonious Society; Lexington Books: Lanham, MD, USA, 2008.

70. Naustdalslid, J. Circular economy in China-The environmental dimension of the harmonious society. Int. J. Sustain. Dev. World Ecol. 2014, 21, 303-313. [CrossRef]

71. Parton, C. China's Acute Water Shortage Imperils Economic Future. Financial Times, 27 February 2018. Available online: https://rusi.org/in-the-news/china\%E2\%80\%99s-acute-water-shortage-imperils-economicfuture (accessed on 13 November 2018).

72. Zhou, Y.; Li, H.; Wang, K.; Bi, J. China's energy-water nexus: Spillover effects of energy and water policy. Glob. Environ. Chang. 2016, 40, 92-100. [CrossRef]

73. Zhou, D.; Zhang, Z.; Shi, M. Where is the future for a growing metropolis in North China under water resource constraints? Sustain. Sci. 2015, 10, 113-122. [CrossRef]

74. Jiang, M. Towards Tradable Water Rights: Water Law and Policy Reform in China; Springer International Publishing: New York, NY, USA, 2018.

75. Li, D. Overcapacity, Over-Withrawal: How Tackling Coal Power Overcapacity Can Ease Water Stress; Greenpeace: Beijing, China, 2017.

76. National Development and Reform Commission (NDRC). The 13th Five-Year Plan for Economic and Social Development of the People's Republic of China (2016-2020); NDRC: Beijing, China, 2016.

77. NDRC. The 13th Five-Year Plan for Energy Development; NDRC: Beijing, China, 2016. (In Chinese)

78. NDRC. Energy Supply and Consumption Revolution Strategy (2016-2030); NDRC: Beijing, China, 2016. (In Chinese)

79. NDRC. 13th Five-Year Plan for Ecological E Environmental Protection (2016-2020); NDRC: Beijing, China, 2016.

80. Qiu, J. China faces up to groundwater crisis. Nature 2010, 466, 308. [CrossRef] [PubMed]

81. Ministry of Water Resources. National Comprehensive Plan for Water Resources; Ministry of Water Resources: Beijing, China, 2010.

82. Xu, Y. China's Water Resource Tax Expansion; China Water Risk: Hong Kong, China, 2018.

83. Gong, C.; Liu, C.; Song, L. Comprehensive Resource Tax Reform Kicked Off in China-Water Resource Tax Piloted in Hebei Province; Deloitte: Beijing, China, 2016.

84. Beijing Water Authority. Beijing Water Resources Bulletin 2016; Beijing Water Authority: Beijing, China, 2017.

85. Ministry of Industry and Information Technology. Market Access Standard for Coking Industry; Ministry of Industry and Information Technology: Beijing, China, 2014. (In Chinese)

86. Beijing Municipal Administration of Quality and Technology Supervision (BMAQTS). The Stipulation of Energy Consumption of Municipal Wastewater Treatment; BMAQTS: Beijing, China, 2015.

87. Qiu, G.Y.; Li, W.; Li, L.; Zhang, Q.; Yang, Y. Water and Energy Nexus in China: Current Situation and Future Perspective in Energy Industry, Water Industry and Agriculture. J. Fundam. Renew. Energy Appl. 2014, 4, 1000138. [CrossRef]

88. Donaldson, J.A. China' s administrative hierarchy: The balance of power and winners and losers within China's levels of governmen. In Assessing the Balance of Power in Central_Local Relations in China; Donal, J., Ed.; Routledge: New York, NY, USA, 2016; pp. 105-137.

89. Van Rooij, B. Centralizing Trends and Pollution Law Enforcement in China. China Q. 2017, 231, 583-606. [CrossRef] 
90. Voïta, T. Xi Jinping's Institutional Reforms. Environment over Energy? Edito Energie; Institut Français des Relations Internationales: Paris, France, 2018.

91. Hu, P.; Chen, N.; Li, Y.; Xie, Q. Efficiency Evaluation of Water Consumption in a Chinese Province-Level Region Based on Data Envelopment Analysis. Water 2018, 10, 793. [CrossRef]

92. Wang, J.-M.; Shi, Y.-F.; Zhang, J. Energy efficiency and influencing factors analysis on Beijing industrial sectors. J. Clean. Prod. 2017, 167, 653-664. [CrossRef]

93. Li, J.; Xiang, Y.; Jia, H.; Chen, L. Analysis of Total Factor Energy Efficiency and Its Influencing Factors on Key Energy-Intensive Industries in the Beijing-Tianjin-Hebei Region. Sustainability 2018, 10, 111. [CrossRef]

94. Andrews-Speed, P. The Institutions of Energy Governance in China. Note de l'IFRI; Institut Français des Relations Internationales: Paris, France, 2010.

95. Van Dijk, M.P.; Liang, X. Beijing, managing water for the eco city of the future. Int. J. Water 2012, 6, 270. [CrossRef]

96. Kostka, G. Barriers to the Implementation of Environmental Policies at the Local Level in China; World Bank Group: Washington, DC, USA, 2014.

97. Habich-Sobiegalla, S. How Do Central Control Mechanisms Impact Local Water Governance in China? The Case of Yunnan Province. China Q. 2018, 234, 444-462. [CrossRef]

98. Wong, C.; Karplus, V.J. China's War on Air Pollution: Can Existing Governance Structures Support New Ambitions? China Q. 2017, 231, 662-684. [CrossRef]

99. Gilley, B. Local Governance Pathways to Decarbonization in China and India. China Q. 2017, 231, 728-748. [CrossRef]

100. Cui, W. Resource tax reform started in July [in Chinese]. Economic Daily, 28 June 2016.

101. Wu, J.; Chang, I.-S.; Bina, O.; Lam, K.-C.; Xu, H. Strategic environmental assessment implementation in China - Five-year review and prospects. Environ. Impact Assess. Rev. 2011, 31, 77-84. [CrossRef]

102. Liao, X.; Zhao, X.; Hall, J.W.; Guan, D. Categorising virtual water transfers through China's electric power sector. Appl. Energy 2018, 226, 252-260. [CrossRef]

103. Zhao, X.; Li, Y.P.; Yang, H.; Liu, W.F.; Tillotson, M.R.; Guan, D.; Yi, Y.; Wang, H. Measuring scarce water saving from interregional virtual water flows in China. Evironmental Res. Lett. 2018, 13, 054012. [CrossRef]

104. Tang, B.; Yang, Q. Water pollution governance from the perspective of coordinated development: The case of pollution governance in Poyang Lake water. Theor. Explor. 2014, 5, 24-31. (In Chinese)

105. Huang, Q.; Xu, J. Scales of Power in Water Governance in China: Examples From the Yangtze River Basin. Soc. Nat. Resour. 2017, 30, 421-435. [CrossRef]

106. Lieberthal, K. China's Governing System And Its Impact on Environmental Policy Implementation. China Environ. Ser. 1997, 1, 3-8.

107. Rasul, G. Managing the food, water, and energy nexus for achieving the Sustainable Development Goals in South Asia. Environ. Dev. 2016, 18, 14-25. [CrossRef]

108. Visseren-Hamakers, I.J.; Glasbergen, P. Partnerships in forest governance. Glob. Environ. Chang. 2007, 17, 408-419. [CrossRef]

(C) 2020 by the authors. Licensee MDPI, Basel, Switzerland. This article is an open access article distributed under the terms and conditions of the Creative Commons Attribution (CC BY) license (http://creativecommons.org/licenses/by/4.0/). 